\title{
Harmonization of Accounting Standards through Internationalization
}

\author{
Nikhil Chandra Shil, ACMA (Corresponding Author) \\ Department of Business Administration \\ East West University \\ 43, Mohakhali C/A, Dhaka - 1212, Bangladesh \\ Tel: 9887989(Off.) ext 253, 01819289589 (M) E-mail: nikhilacc@yahoo.com \\ Dr. Bhagaban Das \\ P.G. Department of Business Management, Fakir Mohan University \\ P. O.: Balasore, Pin.: 756019, Orissa, India \\ E-mail: bhagaban_fm@yahoo.com \\ Alok Kumar Pramanik \\ Department of Commerce, Bhatter College \\ P. O.: Dantan, Pin. : 721426, Paschim Medinipur, West Bengal, India \\ E-mail: alokdantan@sify.com
}

\begin{abstract}
The journey to have a common set of accounting standards started long before to give it a professional shape and essence. And accountants all over the world feel the necessity to shorten the gap among different streams of accounting practices through harmonization. Still, we have a couple of strong variants of accounting practices (say, for example, US GAAP, UK GAAP, IAS etc.) over the world existed and practiced simultaneously. These variants are working as threats towards harmonization of accounting practices. However, the profession has also witnessed some improvements in recent years in the process of global convergence putting some ray of hope. International and even local standard setting bodies have come up with projects of harmonization and in most of the cases became successful. The day is not far away when we will observe that accounting world is controlled and guided by a single set of standards giving it a status of legal discipline in true sense. The paper focuses on this harmonization issue, its current status, challenges with special reference to Indian perspective.

Keywords: Harmonization of Accounting Standards, International Accounting Standards, International Financial Reporting Standards, Generally Accepted Accounting Principles, Securities and Exchange Commission, International Accounting Standards Committee, Convergence of accounting standards.
\end{abstract}

\section{Introduction}

Harmonization of accounting standards has become a highly demanded issue of discussion and debate among accounting professionals around the globe. Accounting Standards are the authoritative statements of best accounting practices issued by recognized expert accountancy bodies relating to various aspects of measurements, treatments and disclosures of accounting transactions and events, as related to the codification of Generally Accepted Accounting Principles (GAAP). These are stated to be the norms of accounting policies and practices by way of codes or guidelines to direct as to how the items, which make up the financial statements, should be dealt with in accounts and presented in the annual accounts. In fact, such statements are designed and prescribed to improve and benchmark the quality of financial reporting. They bring about uniformity in financial reporting and ensure consistency and comparability in the data published by enterprises. These are aimed at furnishing useful information to different users of the financial statements, such as shareholders, creditors, lenders, management, investors, suppliers, competitors, researchers, regulatory bodies and society at large.

The process of harmonization gives the global community a single entity. The diversity of stockholding doesn't matter today if the accounting system can generate general purpose financial statements in real sense. Thus, along with the process of globalization, the awareness of investors in capital markets has increased manifold and the size of investors 
is multiplying. Foreign institution investors (FIIs) are investing in significant volume globally, as also are several Indian companies through GDRs (Global Depository Receipts) and ADRs (American Depository Receipts). Hence, the need for harmonization of accounting standards has been strongly advocated globally in order to faster the economic decision-making process. Accounting has already bagged the status of the' language of the business' that requires reporting of the affairs in a commonly understandable way. At the World Bank Conference held in 1999, Jules W. Muis aptly states "....power to control the language of business is important. Standard setters will come ahead as the world grows smaller, and economic independence is no longer an option but a reality. So it happens that today a good observer can see the preparations of battle for the control of the international language of business slowly unfolds..."

In this context, the statement of Harvey Pitt, US SEC Chairman at SEC Conference, (2002) is worth mentioning, "High quality global accounting standards are needed to improve the ability of investors to make informed financial decisions. Companies must keep pace with this progress in order to promote and protect their business credibility in the international market place."

It is for this reason that the convergence of accounting standards is so important. The process of convergence is accepted as the key factor to implement a single set of accounting standards across the globe. The paper follows a scholarly search approach to discuss the recent status of harmonization in accounting practices.

\section{Objectives}

The objectives of current study are very straight forward. The very basic issue is to explain the need of harmonization in practices. Later on, it focuses on the regulatory authorities who are working actively to bring the convergence into practice. The paper also presents the success stories in the process of harmonization with the challenges ahead. Indian status has been addressed separately to report the situation of a developing county.

\section{Rationales of Harmonization of Accounting Standards}

To allow the gains from the global economy to be fully realized, it is argued that accounting policy should be standardized among nations. This "harmonization" of accounting standards will help the world economy in the following ways: by facilitating international transactions and minimizing exchange costs by providing increasingly "perfect" information; by standardizing information to world-wide economic policy-makers; by improving financial markets information; and by improving government accountability. However, some specific points are presented below addressing the rationality of harmonization.

A harmonization of accounting policy would help provide a "level playing field" globally. Regulators and auditors will be receiving the same information, facilitating the evaluation process. In the absence of free trade, international accounting standards will allow nations' tariffs, quotas and other trade restraint mechanisms to be more accurate and less risky for those engaged in trade. Investors and managers will be able to make more valuable decisions. World resources will be better managed and allocated.

The recent expansion of international capital markets and availability of instantaneous global communication have placed on accounting the onus to provide useful and comparable information across international boarders (Rivera, 1989). On many stock exchanges, currently, foreign listings are a large percentage of total listings (http://www.fibv.com). As per ICAI estimates, $20 \%$ of total listing on New York Stock Exchange (NYSE) is of foreign origin. In case of London Stock Exchange, this is 16\% and in Luxembourg, the percentage is 82\%. On 12 March 2002, the European Parliament voted overwhelmingly in favor of the EU Commission's proposal that all EU listed companies must follow standards issued by the International Accounting Standards Board (IASB) in their consolidated financial statements starting no later than 2005. Over 7,000 EU listed companies are directly affected by this proposal (Samir, 2003).

The rapid growth of international trade and internationalization of firms, the developments of new communication technologies, and the emergence of international competitive forces is perturbing the financial environment largely. Under this global business scenario, the residents of the business community are badly in need of a common accounting language that should be spoken by all of them across the globe. A financial reporting system of global standard is a prerequisite for attracting foreign as well as present and prospective investors at home alike that should be achieved through convergence of accounting standards (Hati and Rakshit, 2002). ICAI president K. S. Vikamsey (2001) is of opinion that 'People who invest overseas naturally want to be able to keep track of the financial health of the securities issuers. Convergence of accounting standards is the only means to achieve this. Only by talking the same language one can understand each other across borders.'

With the absence of harmonization in accounting standards the additional cost of financial reporting along with the difficulties that multinational groups faces in the manner in which they undertake transactions becomes critical. It is quite possible for a transaction to give rise to a profit under one accounting standard, whereas it may require a deferral under another standard. Thus, multinationals working in both the US and the UK face a good deal of trouble to prepare consolidated financial statements. When a multinational company has to report under the standards of both of the 
countries it might lead to some extremely odd results. For instance,

Daimler Benz, who was the first German to secure stock market listing in the United States, reported a net profit of DM $158 \mathrm{~m}$ for the six months to June 1998 based on German GAAP. The U.S GAAP reconciliation statement revealed that the company had incurred a loss of DM. 949m. Similarly, British Telecom Inc. reported a net profit of $£ 1767$ for the year ended 31-3-1994 under the UK GAAP but under the US GAAP reconciliation, the net profit reduced to $£ 1476$.

Harmonization is not an end by itself, but it is a means to an end. Adoption of different accounting standards causes difficulties in making relative evaluation of performance of companies. This phenomenon hinders the valuation and consequently the decision making process. There are numerous instances in India and around the world of bad accounting practices leading to corporate failures. Corporations wish non-recurrence of another Enron and like.

Another significant benefit that is expected to accrue from global convergence of accounting standards relates to cross-boarder mergers and acquisitions facilitation. Last though not the least, it improves the quality of financial reporting throughout the globe.

\section{Institutional Efforts of Harmonization}

A number of international organizations are working to reduce the differences in accounting standards between nations and trying to eliminate all necessary differences (Nair and Frank, 1980). The concept of convergence of accounting standards relates back to $19^{\text {th }}$ century when the idea of "International Accounting Standards" was germinated in the first International Congress of Accountants held at St. Louis in 1904. Again in 1957, when $7^{\text {th }}$ International Congress of Accountants held in Amsterdam, Mr. Jacobkraayenhof, spoke on the need of international accounting cooperation and standardization. Latter in 1966, discussions were made among the various professional bodies like the Institute of Chartered Accountants of England and Wales, Canadian Institute of Chartered Accountants and Association of the Institute of Certified Public Accountants of America. The discussions were led by Sir Henry Benson, the then President of the Institute of Chartered Accountants of England and Wales and ultimately a study group was formed to conduct comparative studies on the accounting thoughts and practices among participating countries. It conducted about twenty studies on accounting and auditing topics during its eleven years lifetime. Ultimately, the senior officers of the study group decided to establish international standards. The meeting was held in 1972 , and in the $10^{\text {th }}$ International Congress of Accountants at Sydney, the International Coordination Committee for Accounting Profession (ICCAP) was formed to lay the groundwork for the establishment of a formal organization for the International Accounting Standards. The International Accounting Standards Committee (IASC), now International Accounting Standards Board (IASB) came into existence as a result of an agreement by 16 accounting bodies representing 9 nations, i.e., Canada, Australia, France, Japan, Germany, Mexico, Netherlands, United Kingdom and the United States of America on 29th June 1973, with its secretariat and head quarters at London (http://www.iasplus.com).

At present IASC has 153 accounting bodies representing 112 countries. It has so far issued 41 standards to harmonize the diverse accounting standards and policies at present in use in different countries. Barring Canada, Japan and the US, all countries have accepted these standards. The Organization for Economic Co-operation and Development (OECD) has approved a code of conduct for multinational enterprises for harmonization of national and international bodies. The UN Commission on Transnational Co-operation made efforts to establish disclosure standards for multinational corporation operating in the Third World Countries. The Accountants International Study Group (AISG) publishes fifteen comparative studies in order to harmonize financial accounting practices. The international Federation of Stock Exchanges has recommended that its members make compliance with the IASC accounting standards as a condition for listing stock (Most, 1984). These are undoubtedly some milestones on the way of harmonization.

\section{Fast Facts in the Process of Convergence}

The International Accounting Standards Committee (IASC), constituted in 1973 has passed through many phases of its journey to come to this present stage. It is felt pertinent to discuss all these here briefly for the knowledge of our esteemed readers.

In the year 1995, IASC entered into an agreement with International Organization on Securities Commission (IOSCO) on a mission to complete "comprehensive core set of Standards" that could be used for cross-boarder and national listings. In fact, this was due to growing recognition of the need for global accounting standards.

To give proper direction on how to interpret these standards led to the setting up of the Standards Interpretations Committee (SIC) in 1997.

In December 1999, the board of the International Accounting Standards Committee has approved proposal to make changes in the structure of the committee with a view to achieve global convergence.

On May 2000, one most important breakthrough was reached when the International Organization on Securities Commission (IOSCO) accepted 30 core International Accounting Standards. This backing by IOSCO for the use of International Accounting Standards by member stock exchanges led to the acceptance and recognition of the 
International Accounting Standards Committee (IASC) as a worldwide standard setter. Further, it was followed by the reformation of IASC to International Accounting Standards Board (IASB) in 2001. Consequently, IAS is now renamed as International Financial Reporting Standards (IFRS), have brought into limelight. Consequently, in the same year the US Securities and Exchange Commission (SEC) suggested the acceptance of IAS for use in cross-border listings in the US, without reconciliation to results under the US-GAAP (Madan, 2002).

In 2001, the international fraternity of accountants took stock of the situation and constituted the International Accounting Standards Board (IASB) to evolve and prescribe norms for treatment of several items in the preparation and presentation of financial statements. IASB adopted all the 41 standards issued by the IASC till 2001. These standards were thoroughly revised and updated in view of the changes in industry and the need for rationalization.

In October 2002, a Memorandum of Understanding (MOU) was signed between the IASB and the FASB, the two major players in the accounting standards arena, which is well known as Norwalk agreement. The two grand bodies agreed to put their best efforts to make their financial reporting standards fully compatible. The Norwalk agreement was welcomed throughout the accounting circles including the Securities and Exchange Commission (SEC).

The International Financial Reporting Interpretations Committee (IFRIC) was constituted to replace the SIC. This committee meets periodically to discuss and spell out their interpretations. It deals with matured as well as emerging issues. The former are those covered by existing standards but not satisfactorily practiced, and the latter are new topics relating to an existing IAS but not considered while developing the standard.

The last milestone in the process of convergence was done on 12 March 2002, when the European Parliament voted overwhelmingly in favor of the EU Commission's proposal that all EU listed companies must follow standards issued by the International Accounting Standards Board in their consolidated financial statements starting no later than 2005. This put an "end to the current Tower of Babel in financial reporting". This decision also seems to have placed IAS firmly in the driver's seat as the eventual global standard. Canada, Australia, and a number of other countries have announced intention to adopt IAS. United States, which has shown a preference for maintaining its independent standards setting body for a pretty longer period, is evidencing interest in convergence of accounting standards.

\section{Present Global Scenario}

The countdowns to the harmonization of national and international accounting standards and an improvement in the quality of financial reporting at a global level are best tracked chronologically.

The current world scenario on the subject of harmonization gets going on 12 March 2002, when the EU Commission directed all European companies trading in the European Securities Market to adopt IAS in 2005, and all non- European companies (following US GAPP or any other standards) up to 2007.

In June 2004, the Australian Accounting Standards Board (AASB) had issued standards and interpretations that all accounting standards of Australia that are equivalent to International Financial Reporting Standards (A IFRS) must be adopted from 2005 in their country.

Many countries like Korea, Barbados, Trinidad and Tobago, Zimbabwe, Mongolia, Malta, and Uganda are adopting IAS. The information about accounting principles applicable in Syria and Tunisia indicates that they are similar to international accounting standards. At present, all companies and banks in Russia are required to prepare their financial statements in accordance with IAS.

New Zealand's Accounting Standards Review Board (ASRB) and Financial Reporting Standards Board (NZ FRSB) have adopted 36 new accounting standards and 12 interpretations in January 2005. And these formed New Zealand's equivalent of the International Financial Reporting Standards (NZ IFRS). It is going to implement IASB standards with effect from $1^{\text {st }}$ January 2007.

Hong Kong is an important international financial hub. Its stock market ranks second largest in Asia and eight largest in the world in terms of market capitalization. The Hong Kong Institute of Certified Public Accountants (HKICPA), the standard setting body of Hong Kong has been pursing the policy of aligning its standards with IAS since the early 1990s. Most recently, HKICPA has further committed time and resources to support convergence.

Philippines have also adopted national standards that are identical to IFRS from 2005. Singapore has adopted many accounting standards from IFRS that essentially word for word. Now these are known as Singapore's equivalents of IFRS (S IFRS).

Japan, the major player in the global capital market and the second largest capital market in the world, is a strong supporter of IASB. The Japanese Institute of Certified Public Accountants is now working in collaboration with the IASB to make the Japanese standards essentially equivalent to international standards. Japan too has undertaken a joint project in collaboration with IASB to remove the differences between Japanese Accounting Standards (JAS) and IFRS by January 2005. 
The Canadian Accounting Standard Board (CASB) has also announced its intention to adopt International Financial Reporting Standards (IFRS) in five years. Canada's decision to adopt IFRS means that out of original G4 nations, US is the only member that has not gone over to international standards.

In Egypt, Egyptian Accounting standards have prepared to comply with international accounting standards except for certain minor differences to adopt Egyptian economic environment. Therefore, all companies listed in the Cairo Stock Exchanges must follow IAS. Kuwait adopted IAS as its national standards. Therefore, all Kuwaiti companies are following IAS for the purpose of listing. All companies in Jordan, both domestic and foreign, listed in the Amman Stock Exchange must follow IAS. However, in Turkey, foreign companies may follow any one out of three standards, such as, International Accounting Standards, UK GAAP and US GAPP for listing in Istanbul Stock Exchange.

In the Middle East, most of the countries have welcomed the International Accounting Standards. For cases in point, Bahrain, Qatar, Lebanon, and Oman are considering IAS as the replacement to their domestic standards. Of course, Iran and Israel had shown reluctance for the use of International Accounting Standards. In Iran, all companies to be listed in Iranian Stock exchange must have to follow Iranian accounting principles. Similarly all companies must have to follow Iranian accounting principles, if they want to be listed in Tel Alive Stock exchange.

On January 1, 2007, more than 1,100 Chinese companies switched to new accounting standards that brought their books in line with international norms. From next year, the companies will have to apply a new set of 38 standards, under the China Accounting Standards System, that are basically in line with IASB (International Accounting Standards Board) norms. But, there is far more at stake than improving accounting practices at China's listed firms. Chinese companies are increasingly looking overseas for funds and acquisitions. Adopting international standards will make this easier by increasing their transparency and credibility.

In Bangladesh, the Institute of Chartered Accountants of Bangladesh (ICAB) set standards for the country through its Technical and Research Committee. Till date, it has adopted all eight IFRSs and twenty six IASs. In terms of standards, the gap between IASs and the standards as followed in Bangladesh is insignificant though some national laws give contradictory prescription in single situation. Another milestone reached by Bangladesh is that it has enacted the Financial Reporting Act 2008 to control financial reporting activities and, at the same time, to do the watchdog function of the accounting and auditing profession that will further strengthen the harmonization process.

From above deliberations, it can be believed at this moment that, the IOSCO's endorsement of the IASC standards has paved the way for unification of accounting standards globally and emergence of the true artificial language designed for global use in the field of accounting (Srkant, 2005). Today the world of accounting feels that International Accounting Standards should be that language, as it is the only set of standards that has been prepared through wide international consultations and participations.

\section{What will happen if USA does not adopt IAS?}

Now it is realized that, barring very few, almost all countries of the world are interested to follow IAS as their accounting standards. USA is the only main country reluctant to adopt it. Now question arises what will happen if super-power of the world and a highly developed economy like USA does not adopt IAS?

Executive search firm, Russell Reynolds' survey of chairmen across 145 European companies has found: (a) over half the chairmen of companies with US listings said they would consider de-listing because of Sarbanes-Oxley, in spite of the difficulties in taking shares off the US exchanges; (b) $70 \%$ of those heading companies not yet listed in the US said Sarbanes-Oxley would dissuade them from seeking a US listing.

With the relatively tighter regulation in the US, several large companies are understood to be evaluating other capital markets that accept IFRS (Memani, 2006). While such situations provide an opportunity for IFRS to flourish, it would still be inappropriate to stay limited to that perspective. This is because IFRS stands a fair chance on its own, with its acceptance by EU, and also given the fact that many countries have traditionally followed IFRS or IFRS-inspired national accounting standards.

\section{Harmonized Accounting Standards: Issues and Challenges}

In spite of all, achieving global convergence in accounting standards is not an easy task. There are a number of issues to overcome.

First of all, there seems to be a reluctance to adopt the International Accounting Standards Committee (IASC) norms in the US. This is definitely a problem. The US is the largest market and it is important for IASC standards to be harmonized with those prevailing there. The US lobby is strong, and they have formed the G4 nations, with the UK, Canada, and Australia (with New Zealand) as the other members. IASC merely enjoys observer status in the meetings of the G4, and cannot vote. Even when the standards are only slightly different, the US accounting body treats them as a big difference, the idea being to show that their standards are the best. However, except US all other members of G4 has adopted the IAS more or less to some extent. 
Second, accounting standards have been developed in different countries under different legal, economic, social and cultural environments. For this reason there exists such diversity in accounting standards among the countries through the globe. If convergence is to be achieved, it is first necessary to arrive at an agreement as to the central objective of financial reporting. The IASB standards are oriented to serve the needs of investors and capital markets. Countries that have a different financial reporting philosophy would find it extremely difficult to harmonize their domestic standards with International Financial Reporting Standards.

Third, the quality of financial reporting depends on the quality of accounting standards as well as the effectiveness of the process by which those standards are implemented. Adequate regulatory and other supports are necessary to ensure proper implementation of standards. Implementation of accounting standards is not an easy task. In spite of convergence, there is no assurance that they will be implemented with same amount of vigor in every jurisdiction.

Last, convergence of accounting standards with international approach will inevitably raise the questions of rules versus principles. IASB standards are principles-based. Thus the countries that have rules-based standards are expected to experience considerable difficulty in harmonization of their standards with IFRS.

There are challenges that IASB and nations adopting IFRS need to address in the coming days. One big challenge for countries adopting IFRS is the shortage of manpower and more particularly, IFRS-trained manpower. For case in point, with just six months to go before China's listed companies adopt IFRS, demand for accountants is rising and could run into millions in the coming years, if the new standards are rolled out for all of the country's companies and not just the listed ones.

Accountants say that the challenge for China, as it scrambles to meet the accounting shift deadline, will lie in getting its over-1,100 listed companies to establish the appropriate financial reporting systems and in training enough qualified accountants by January. The risk is that some of these companies may fail to make the transition on time. Estimates reveal that China has a shortfall of 300,000 qualified accountants and is likely to require a further three million over the coming years to keep pace with its current rate of economic growth.

\section{Status of Indian Accounting Standards}

India is a member of IASC. The Institute of Chartered Accountants of India (ICAI), the apex body of accounting and auditing, constituted an Accounting Standards Board (ASB) on April 21, 1977, to pronounce standards on various items of the financial statements. The current Indian accounting standards are of good quality in most instances and in fact, are practically the same as IASs. The statutory audit was the only enforcement mechanism till 1999. It was in 1999 when the Government of India constituted the National Advisory Committee on Accounting Standards (NACAS), an advisory body on accounting standards by inserting Section 210A in the Companies (Amendment) Act 1999. So far, the NACAS has advised the adoption of 27 accounting standards developed by ASB.

In support of its commitment to adopt IAS; the ASB is examining the various standards revised by IASB to initiate revision in its corresponding. This Board has been releasing standards from time to time. Certain of the standards have also been revised/deleted/curtailed in the light of new and additional standards as well as the experience of the industry. Moreover, the Board has also prepared a comparative statement listing the IAS with corresponding Indian Accounting Standards, and also the standards which are irrelevant in the context of present economic and business scenario (Chowdhury, 2000). Till now, 29 Accounting Standards have been issued by the ICAI as against the 41 International Accounting Standards. There are also five International Financial Reporting Standards (IFRS).

In India, since the ASB is not yet functional, the accounting standards as pronounced by the ICAI are adaptable by every entity whose financial statements are subject to audit.

\section{Grounds of Diversity between Indian Accounting Standards and IAS}

India is slowly entering into the arena of accounting standards. But the progress of formulation of accounting standards has been very slow as compared with the developments at international levels. However, some of the accounting standards in India conform to the International Accounting Standards. Still there are significant variations between these two. Efforts are on to counterpart Indian accounting standards with the IAS. A study of their variations would be crucial for bridging the gaps (Reddy, 2000).

For India, the multiplicity of standard setters leads to delay and lack of direction. The increased complexity of the fair valuation models as prescribed by international standards requires extensive valuation/objective professional judgments, integrity and uniformity of approach, which may not be easily achievable across all countries-particularly in the emerging economies like India.

It may be noted that in several important areas, when the Indian Standards are implemented, the accounting treatment in these areas could lead to differences in the restatement of accounts in accordance with IAS. Some of these areas include: a) Consolidated financial statements, b) Accounting for income taxes, c) Financial Instruments and d) Intangible Assets. Another reason for the prevailing divergent accounting practices in the Indian Accounting Standards is the provisions of 
the Income Tax Act 1961 and Indian Companies Act 1956. They do not go together. Sometimes, the prescriptions are contradictory on a similar issue.

\subsection{Company law and Accounting Standards}

In India, though accounting standards setting is presently being done by ICAI, one could discern a tentative and halfhearted foray by company legislation in to the making of accounting rules of Measurement and reporting. This action by itself is not the sore point but the failure to keep pace with the changes and simultaneously not allowing scope for some one else to do it is disturbing.

A study of the requirement of company law regarding the financial statements reveal several lacunae like earning per share, information about future cash flows, consolidation, mergers, acquisitions etc.

\subsection{Income Tax Act and Accounting Standards}

The Income Tax Act does not recognize the accounting standards for most of the items while computing income under the head "Profits \& Gains of Business or Profession". Section 145(2) of the I. T. Act has empowered the Central Government to prescribe accounting standards. The standards prescribed so far constitute a rehash of the related accounting standards prescribed by ICAI for corporate accounting. On a close scrutiny of these standards one is left wondering about the purpose and value of this effort. Examples are application of prudence substance over form, adherence to principles of going concern etc.

\subsection{Other regulations and accounting standards}

In respect of banks, financial institutions, and finance companies the Reserve Bank of India (RBI) pronounces policies among others, revenue recognition, provisioning and assets classifications.

Similarly the Foreign Exchange Dealers Association (FEDAI) provides guidelines regarding accounting for foreign exchange transactions. Since the Securities \& Exchange Board of India (SEBI) is an important regulatory body it would also like to have its own accounting standards and in fact, it has started the process by notifying cash flow reporting format. It is also in the process of issuing a standard on the accounting policies for mutual funds. It appears as if several authorities in India are keen to have a say in the matter of framing accounting rules of measurement and reporting. The tentative and half-hearted legal and regulatory intervention in accounting in India has come in the way of development of robust, continuously evolving and dynamic accounting theory and standards (http://www.icai.org). In spite of this, India's adoption of IAS is inevitable. When the whole world is adopting one language, it will be simply impossible on the part of India to hold it out for a too long period.

\section{The Conclusion}

Harmonization is the process by which differences in practices among countries are reduced (Doupnik, 1987). The case of harmonizing accounting practices and principles at the international level is stronger today that it has ever been (McComb, 1982). Even, the IASC itself is concerned with removing unnecessary differences in accounting principles and practice throughout the world (McComb, 1982). Overwhelmingly, the harmonization of accounting practices suffers from a lack of synchronization between the issuance of standards at the national level in different countries and the formulation of standards by the IASC (Rivera, 1989).

At the same time, both success and failure exists in the process of harmonization. For example, the American Institute of Chartered Accountants (AICPA) adopts the view that US GAAP being superior to IASs and its member must necessarily comply with the former (Most, 1984). As we know that it is an age of globalization, there is no conceptual boundary among the nations. And this is not difficult at all to choose superior standards through the current process of setting the standards. The attainment of a single set of accounting and reporting standards is the demand of the time. We will fall behind if this harmonization process takes more time.

Many of the initial hurdles in the process of harmonization have been overcome and much progress towards convergence of accounting principles and procedures among countries has already been achieved. Convergence initiatives are now working much more effectively than ever before. Differences are still there but they are narrowing. It is expected that the pace of progress in the sphere of convergence will accelerate further in the coming years. In Indian perspective, it will continue to adopt IASs/IFRSs in the near future with few modifications to cater to the requirements of local climate.

Setting IFRS under new regulatory framework is also a notable success in harmonization. IAS permits some alternative practices that has been reduced in IFRS to make the prescription common to all so that following same standards cannot generate varying practices. We expect that this process will ultimately set new benchmark for achieving harmonization in both national and international level.

\section{References}

Chowdhury, A. K. (2000). Compliance with accounting standards in India, why and how? Management accountant, ICWAI, March 2000. 
Doupnik, T. S. (1987). Evidence of International Harmonization of Financial Reporting. International Journal of Accounting, 23(1), 12-27.

Hati, W. J. and Rakshit, D. (2002). Integrating accounting standards - A step towards harmonization. Management accountant, ICWAI, May 2002.

http://www.fibv.com (Retrieved on 19.05.2007).

http://www.iasplus.com (Retrieved on 12.07.2007).

http://www.icai.org/resource/o_ac_standard.html (Retrieved on 27.09.2007).

Madan V. (2002). Re-Statement under US GAAP. India Infoline Newsletter, IMT Ghaziabad.

McComb, D. (1982). International Accounting Standards and the EEC Harmonization Program: A Conflict of Disparate Objective. International Journal of Accounting, spring, 35-48.

Memani, R. (2006). Accounting a Milestone for Global Markets. The Financial Express, July 27, 2006.

Most, K. S. (1984). International Conflict of Accounting Standards, A Research Monograph, No. 8. The Canadian Certified General Accountants Research Foundation.

Reddy, K. R. (2000). Accounting standards and Gaps in Practices in India. Management accountant, ICWAI, April 2000 .

Rivera, J. M. (1989). The Internationalization of Accounting Standards: Past Problems and Current Perspectives. International Journal of Accounting, 24(4), 320-342.

Samir, M. S. (2003). Harmonization of Accounting Standards. Chartered Accountant, ICAI, January 2003.

Srkant, S. (2005). Accounting Standards - will the World be talking same language? Chartered Accountant, ICAI, February 2005. 